\title{
Investigation of Essential Oil Composition Variation with Age of Eucalyptus Globulus Growing in Ethiopia
}

\author{
Yoseph Shiferaw, Abayneh Kassahun, Abebe Tedla*, Gezu Feleke, Amare Ayalew Abebe \\ Department of Chemistry, Debre Berhan University, Debre Berhan, Ethiopia
}

\begin{abstract}
Various types of aromatic and medicinal plants are available in Ethiopia from which the essential oil can be extracted for different purpose. Eucalyptus plant is most common among them. Despite its availability the variation of essential oils of Eucalyptus globulus with ages, the chemical constituents of Eucalyptus globulus essential oil of Ankober origin has not previously been examined. Thus, the aim of this study is to assess the variation of essential oil with ages in Eucalyptus globulus tree grown at Ankober district, Ethiopia. Most part of Ankober is covered by Eucalyptus globulus, locally known as 'Nech-Baharzaf. Essential Eucalyptus leaves having different ages were collected and subjected to steam distillation to determine the quality and quantity of essential oil (main components of the oils). Eucalyptus globulus leaves aged 3, 5, 8, 12, 20, 35 and 100 were compared. All the leaves were collected from the same agroecological zone and in the same season to avoid oil content variation with climate change and agroecology. Chemical composition of the essential oils was analyzed by GC/MS and alpha-Pinene, d-limonene and cineol were the main constituents. The highest amount of eucalyptol (73.90\%) presented in plant aged 100 years whereas alpha-Pinene (20.05\%) and d-limonene $(6.17 \%)$ detected in essential oil of plants aged three. The main constituent of the oil is cineole, ranging from $61.04 \%-73.90 \%$ which might suggest age variation has significant impact on essential oil content composition.
\end{abstract}

Keywords:

Eucalyptus globulus; Essential oil; Hydro-distillation; 1, 8-cineol; Age variation

\section{INTRODUCTION}

The genus Eucalyptus from Myrtaceae family, originally from Australia, has been distributed all over the world due to its easy adaptability, ease of cultivation, tolerance to a wide range of environmental conditions and fast growth. The Eucalyptus consists of approximately 900 species [1-3]. Reports indicate that more than 300 species of this genus are naturally rich in essential oil content in their leaves. Few of these species are known for their high content of 1, 8-cineole (more than 70\%). Hydrocarbons, aromatic derivatives, terpenes and their oxygenated derivatives such as mono- and sesqui-terpenoids, alcohols and esters are the basic components found in essential oils $[4,5]$. The essential oil extracted from the leaves of Eucalyptus has been widely used in various sectors including in pharmaceutical, cosmetics, and food industries based on their compositions [6-8]. Cineole is the most important chemical constituent that determines the medicinal value of Eucalyptus oil [9]. According to British and European pharmacopeia the oil should contain a minimum of $70 \%$ 1,8-cineole to be considered as pharmaceutical grade Eucalyptus oil [10-12]. Currently there is growing tendency to use natural products as ingredients. Essential oil is one of the natural products that is gaining significant attention to be used as ingredients in drinks, foods, cosmetics and toiletries $[13,14]$. As a result, the scientific interest in this area is continuously increasing since demand of customers for essential oils are increasing for different applications. Many countries have approved extracts of Eucalyptus leaves as food additives [15]. For instance, United States Food and Drug Authority (FDA) have categorized the essential oil from Eucalyptus as safe and non-toxic. Europe has

Correspondence to: Abebe Tedla, Department of Chemistry, Debre Berhan University, Debre Berhan 445, Ethiopia, Tel: +251946362641; E-mail: abebetedla@gmail.com

Received: April 18, 2019; Accepted: May 06, 2019; Published: May 13, 2019

Citation: Shiferaw Y, Kassahun A, Tedla A, Feleke G, Abebe AA (2019) Investigation of Essential Oil Composition Variation with Age of Eucalyptus Globulus Growing in Ethiopia. Nat Prod Chem Res. 7: 360. DOI: 10.35248/2329-6836.19.7.360

Copyright: (C) 2019 Shiferaw Y, et al. This is an open-access article distributed under the terms of the Creative Commons Attribution License, which permits unrestricted use, distribution, and reproduction in any medium, provided the original author and source are credited. 
accepted the Eucalyptus essences as aromatizers in foods [16]. Likewise, Japan has listed the extract of Eucalyptus globulus as Food Additives due to its antioxidant nature [17]. It is common to observe vaporizing Eucalyptus oil in saunas with the assumption that it removes muscular pains through massaging with the oils, and also it has been widely used for many years by sportsmen for different purposes.

In different countries including Ethiopia, the extracts of Eucalyptus have been used traditionally to treat a wide range of ailments. For instance, hot water extracts of dried and fresh leaves of Eucalyptus globulus are used as analgesic, antiinflammatory and antipyretic remedies for common cold, flu and sinus infection since it is a unique natural products having antiseptic properties and the ability to clear the nasal passages and bronchial tubes making it easier to breathe. They also boil the Eucalyptus leaves in water and inhale the vapor coming out of it to get relief especially from common cold. Numerous investigations have shown that the essential oils of Eucalyptus species possess important biological activities including diaphoretic, disinfectant, antimalarial, antiseptic, analgesic, antiinflammatory, antibacterial and antioxidant properties [18-21]. And hence traditionally it has been widely employed as effective alternatives or complements to synthetic drugs. With the rising significance in the use of EO in both food and pharmaceutical industries, a systematic assessment of the phytochemical extracts has become increasingly essential [22-24]. Today the essential oil from Eucalyptus is marketed in the world in different forms (with other ingredients). For instance, the product named "Vicks Vaporub" which contains Eucalyptus oil as one of the components is manufactured and sold in Europe and North America for different uses.

Eucalyptus has been planted for decades in large parts of Ethiopia for different purposes including firewood, construction and as means of afforestation. Ankober district is a part of the Amhara Region of Ethiopia, located at the eastern edge of the Ethiopian highlands in the North Shewa Zone. This district is one of the areas in which more plantations of Eucalyptus trees has been done for long, and trees with different ages are available. And we have already started to make use Eucalyptus oil from these trees as one of the ingredients to produce laundry detergents and toiletries with good deodorizing and antiseptic properties. Even though several studies have been made on the essential oil content variation with agro-ecological and other factors, no reports indicated the essential oil content variation with the age of trees in the study area except botanical studies. In this work, we focus on the investigation of essential oil chemical content variation with the age of Eucalyptus trees.

\section{MATERIALS AND METHODS}

\section{Study area}

The study was conducted in the area of Ankober woreda. Ankober is one of the woredas in the Amhara Region of Ethiopia, Located at the eastern edge of the Ethiopian highlands in the Semien Shewa Zone at an elevation of about 2,465 meters. It is 42 kilometers to the east of Debre Birhan and about 90 miles $(140 \mathrm{~km})$ northeast of Addis Ababa.

\section{Collection of plant materials}

Leaves of Eucalyptus globulus were collected from locally grown Eucalyptus globulus trees aged 3, 5, 8, 12, 20, 35 and 100 years growing in the Ankober woreda of Ethiopia. The leaves were airdried in the shade at the ambient temperature, protected from the direct light, until further analysis. The identity of the plant specimen was confirmed at the Department of biology by Botanist at Debreberhan University.

\section{Extraction of essential oil}

Extraction of oil from Eucalyptus leaves was carried out by a hydro-distillation. Freshly collected $500 \mathrm{~g}$ leaves were weighed and hydro-distilled for three hours for complete extraction of essential oil, using full glass Clevenger-type apparatus. The oil sample obtained from hydro distillation was freed from water by adding anhydrous sodium sulfate. The essential oil of from Eucalyptus leaves was yellow in color.

\section{Identification of chemical composition}

Determination of the chemical composition of the extracted EO from Eucalyptus globulus was carried out by Gas ChromatographyMass Spectroscopy (GC/MS). GC/MS analysis was performed with HP5890 series II coupled with mass spectrometry HP5972 series detector and an electron ionization system, equipped with a capillary column HP5 $(30 \mathrm{~m}, 0.53 \mathrm{~mm}, 0.25 \mu \mathrm{m}$ film). The carrier gas was helium, with a gas flow of $(0.5 \mathrm{~mL} / \mathrm{min})$. Oven temperature was kept at $50^{\circ} \mathrm{C}$ for $4 \mathrm{~min}$ and programmed to $280^{\circ} \mathrm{C}$ at a rate of $30^{\circ} \mathrm{C} /$ minutes. Injector temperature was $250^{\circ} \mathrm{C}$ and the detector temperature was $280^{\circ} \mathrm{C}$. Mass spectra were taken at $70 \mathrm{eV}$. The samples were diluted in chloroform before analysis. The detected compounds were identified by processing the raw GC-MS data and comparing with mass spectral database and from retention times and mass spectra of standard compounds. Relative amounts of detected compounds were calculated based on GC peak areas.

\section{Component identification}

Identification of the chemical components was based on the comparison of their $\mathrm{GC} /$ retention time while passing through GC columns, which determines the retention time of chemical components present in the essential oil, and then compared with authentic compounds through computer matching with commercial mass spectral libraries.

\section{RESULTS AND DISCUSSION}

\section{Yield of Eucalyptus essential oil}

The yields of Eucalyptus oils extracted from the collected leaves of Eucalyptus globulus varied from 0.95 to $1.32 \%$ on fresh weight basis as presented in Table 1 . The maximum percentage value of EO was obtained for the age of 3 years old plant (1.32\%) while the lowest was 100 years old plants $(0.95 \%)$. The yield of the oil was gradually decreased as the age of the plant increased suggesting that the extraction of the oil depends on age of the trees and maturity of the leaves. That means, young leaves tend to have higher oil yield than adult ones. Several reports also 
shows similar trends in Eucalyptus globulus essential oil yields. For example $0.8-1.21 \%$ of essential oil $(\mathrm{w} / \mathrm{w}$, based on the fresh weight of the mature leaves) in Ethiopia [25], 1.87\% of essential oil (w/w, based on the fresh weight of the leaves) in Algeria [26], $0.08-3.5 \%$ of essential oil $(\mathrm{w} / \mathrm{w}$, based on the fresh weight of the mature leaves) in Bangladesh [27], 1.1\% of essential oil (w/w, based on the fresh weight of the mature leaves) in India [28]. It is noted that there are several factors that affect the yields of Eucalyptus oils such as tree age, leaf age, altitude, season, harvest time and fertilizer [29]. In terms of age, young leaves contain more oil than old leaves, while leaves from older trees gave slightly higher yield [29] that is consistent with our result.

Table 1: Essential oil (EO) yields of Eucalyptus at different age.

\begin{tabular}{|c|c|c|c|c|}
\hline $\begin{array}{l}\text { Age of } \\
\text { globulus } \\
\text { (year) }\end{array}$ & $\begin{array}{l}\text { E. Weight of } \\
\text { leaves } \\
\text { extracted }(g)\end{array}$ & $\begin{array}{l}\text { Weight of } \\
\text { oil } \\
\text { collected (g) }\end{array}$ & $\begin{array}{l}\text { Yield } \\
(\%)\end{array}$ & $\begin{array}{l}\text { Location } \\
\text { collected }\end{array}$ \\
\hline 3 & 300 & 396 & 1.32 & Ankober \\
\hline 5 & 300 & 336 & 1.12 & Ankober \\
\hline 8 & 300 & 330 & 1.10 & Ankober \\
\hline 12 & 300 & 321 & 1.07 & Ankober \\
\hline 20 & 300 & 312 & 1.04 & Ankober \\
\hline 35 & 300 & 291 & 0.97 & Ankober \\
\hline 100 & 300 & 285 & 0.95 & Ankober \\
\hline
\end{tabular}

\section{Chemical composition of essential oil}

A several chemical components, with different retention times, were eluted from the GC column

as indicated by the chromatogram in supporting information (Figures S1-S7) and were further analyzed based on their retention time and mass spectra library search. The relative amount of individual components was calculated based on GC peak areas. The GC chromatogram obtained revealed a high concentration of 1, 8 cineol indicated by presence of large peaks which eluted at about 10 minutes i.e., the main principal component in each sample (in all ages of Eucalyptus globulus) is eucalyptol. Furthermore, the color of the volatile oil extracted from all ages of Eucalyptus globulus trees hydro-distillation were light yellow.

The GC/MS total ion chromatogram of the EO was obtained under the conditions described in the procedure section, and the major identified chemical components are summarized in Table 2. GC/MS analysis revealed the presence of 18, 19, 18, 29, 15, 29 and 15 compounds in Y-3, Y-5, Y-8, Y-12, Y-20, Y-35 and Y-100 representing 99.69\%, 99.69\%, 99.98\%, 99.91\%, 99.54\%, $99.49 \%$ and $99.04 \%$ of the total essential oils respectively. However, those chemical components with very small composition compared to other components were ignored and not included in the Table 2. All the Eucalyptus globulus leaves with the different ages studied contain alpha-Pinene, d-limonene and eucalyptol as the main constituent. The highest amount of eucalyptol (73.90\%) detected in Y-100 whereas alpha-Pinene (20.05\%) and d-limonene $(6.17 \%)$ are highest in percentage in essential oil of Y-3. Figures S1-S7 shows the chromatograms of Eucalyptus globulus having different ages with major peaks. In general, it is evident that adult leaves have higher contents of eucalyptol than younger ones. Other components which are small in concentration are also detected in each sample as indicated in Table 2 and Figures S1-S7.

Table 2: Chemical composition of Eucalyptus globulus essential oils with tree of different ages.

Percentage composition of the extracted oil

\begin{tabular}{|c|c|c|c|c|c|c|c|c|}
\hline \multirow[b]{2}{*}{ RT } & \multirow{2}{*}{$\begin{array}{l}\text { identified } \\
\text { compound }\end{array}$} & & & & & & & \\
\hline & & Y-3 & $Y-5$ & Y-8 & $\mathrm{Y}-12$ & $Y-20$ & Y-35 & $\begin{array}{l}\text { Y-10 } \\
0\end{array}$ \\
\hline 6.13 & Alpha-Pinene & $\begin{array}{l}19.3 \\
9\end{array}$ & $\begin{array}{l}19.0 \\
5\end{array}$ & $\begin{array}{l}17.2 \\
4\end{array}$ & $\begin{array}{l}16.2 \\
9\end{array}$ & $\begin{array}{l}15.5 \\
5\end{array}$ & 13.8 & $\begin{array}{l}13.7 \\
3\end{array}$ \\
\hline 7.35 & Beta-Pinene & 0.83 & 0.77 & 0.54 & 0.5 & 0.53 & 0.36 & 0.48 \\
\hline 7.82 & Beta-myrcene & 0.87 & 0.74 & 0.39 & 0.29 & - & - & 0.22 \\
\hline 8.28 & $\begin{array}{l}\text { Alpha- } \\
\text { Phellandrene }\end{array}$ & 0.31 & 0.51 & 0.15 & 0.09 & - & 0.1 & 0.17 \\
\hline 9 & P-Cymene & 0.31 & 0.5 & 0.43 & 0.45 & 1.37 & 1.06 & 0.66 \\
\hline 9.15 & D-Limonene & 5.87 & 6.17 & 4.86 & 3.51 & 3.51 & 2.93 & 4.03 \\
\hline 9.38 & Eucalyptol & $\begin{array}{l}61.0 \\
4\end{array}$ & $\begin{array}{l}62.0 \\
6\end{array}$ & 65.1 & $\begin{array}{l}68.4 \\
5\end{array}$ & $\begin{array}{l}72.2 \\
4\end{array}$ & $\begin{array}{l}72.1 \\
9\end{array}$ & 73.9 \\
\hline $\begin{array}{l}10.3 \\
2\end{array}$ & $\begin{array}{l}\text { Gamma- } \\
\text { terpinene }\end{array}$ & 0.69 & 0.56 & 0.29 & 0.15 & 0.6 & 0.35 & - \\
\hline $\begin{array}{l}10.8 \\
1\end{array}$ & 1-Octanol & - & - & 1.06 & - & - & - & - \\
\hline $\begin{array}{l}11.5 \\
3\end{array}$ & CMM & 0.59 & 0.69 & 0.32 & 0.25 & 0.36 & - & 0.37 \\
\hline
\end{tabular}

\begin{tabular}{l}
11.9 Undecane $\quad 1.26, \ldots, \ldots$ \\
\hline
\end{tabular}
13.5 Pinocarveol,
4 trans-
$0.310 .97-$

\begin{tabular}{|c|c|c|c|c|c|c|c|c|}
\hline $\begin{array}{l}13.6 \\
2\end{array}$ & Isopinocarveol & - & - & - & 1.27 & 1.91 & 1.46 & 1.6 \\
\hline $\begin{array}{l}14.5 \\
7\end{array}$ & Pinocarvone & - & - & 0.29 & 0.48 & 0.95 & 0.89 & 0.6 \\
\hline $\begin{array}{l}15.2 \\
2\end{array}$ & Terpinene-4-ol & 0.33 & 0.28 & - & 0.19 & - & 0.24 & - \\
\hline $\begin{array}{l}15.6 \\
7\end{array}$ & $\begin{array}{l}\text { Trans-p- } \\
\text { mentha-1(7), } 8 \text { - } \\
\text { dien-2-ol }\end{array}$ & - & - & - & 0.28 & 0.34 & 0.39 & 0.26 \\
\hline
\end{tabular}




\begin{tabular}{|c|c|c|c|c|c|c|c|c|}
\hline $\begin{array}{l}15.8 \\
6\end{array}$ & Alpha-terpineol & & 1.04 & 1.03 & 0.97 & - & 1.4 & - \\
\hline $\begin{array}{l}22.7 \\
5\end{array}$ & 3CMA4A & 2.31 & 3.01 & 4.23 & 3.48 & - & - & 1.34 \\
\hline $\begin{array}{l}25.2 \\
1\end{array}$ & $\begin{array}{l}\text { Alpha- } \\
\text { Gurjunene }\end{array}$ & 0.87 & 0.39 & - & 0.14 & - & - & - \\
\hline 26.4 & $\begin{array}{l}\text { Aromandendre } \\
\text { ne }\end{array}$ & 2.43 & 1.59 & 0.91 & 0.99 & 0.94 & 1.01 & 1.05 \\
\hline $\begin{array}{l}27.2 \\
7\end{array}$ & $\begin{array}{l}\text { Alloaromadend } \\
\text { rene }\end{array}$ & 0.75 & 0.44 & 0.29 & 0.27 & 0.24 & 0.37 & 0.26 \\
\hline 28.7 & Viridiflorene & 0.86 & 0.48 & - & 0.11 & - & - & - \\
\hline $\begin{array}{l}31.2 \\
2\end{array}$ & Epiglobulol & - & 0.28 & - & 0.18 & & 0.26 & - \\
\hline $\begin{array}{l}32.1 \\
7\end{array}$ & (-)-Globulol & 0.77 & 0.82 & 0.62 & 0.72 & 0.55 & 1.05 & 0.37 \\
\hline \multirow[t]{2}{*}{$\begin{array}{l}32.4 \\
6\end{array}$} & Ledol & - & - & - & 0.11 & - & 0.16 & - \\
\hline & & $\begin{array}{l}99.3 \\
6\end{array}$ & $\begin{array}{l}99.6 \\
9\end{array}$ & $\begin{array}{l}99.9 \\
8\end{array}$ & $\begin{array}{l}99.1 \\
7\end{array}$ & $\begin{array}{l}99.0 \\
9\end{array}$ & $\begin{array}{l}99.4 \\
9\end{array}$ & $\begin{array}{l}99.0 \\
4\end{array}$ \\
\hline
\end{tabular}

Y: year; CMM: Cyclohexane, 1-methyl-4-(1-methylethylidene); 3CMA4A: 3-Cyclohexe-1-methanol alpha-alpha 4-trimethyl-acetate.

A comparison was also made regarding the content of monoterpenes in oil samples of Eucalyptus that were collected from Ankober woreda at the age of 3, 5, 8, 12, 20, 35 and 100. The results showed that the volatile oil of the plant possessed a particular quantitative and qualitative chemical composition. 1, 8-cineole determines the business value of the oil and its significance as a raw material for diverse industries. Components such as 1, 8-cineole was found to be the dominant and its percentage composition is agreement with the same tree species reported in other region of the world [25]. Different percentages of 1, 8-cineole in E. globulus leaf oil have been mentioned in the literature: $51.08 \%$ in Algeria, 62.38\%-5.37 in Ethiopia, 67\% in Bangladesh, 54.79\% in India [25-28], 72.71\% in China [30] in which variation might be due to different agroecological zones and other factors. Our finding suggests that as the age of the plant increases, percentage composition of 1, 8cineole increases whereas percentage composition of AlphaPinene (the second most dominant compound) decreases as shown in Table 2.

\section{CONCLUSION}

The extraction of the essential oil from the Eucalyptus globulus aged $3,5,8,12,20,35$ and 100 was carried out by hydrodistillation method. The essential oil content analyzed by GC/MS was found to be in the range of $0.95-1.32 \%$ depending upon the ages of the plant. The GC/MS analysis revealed the presence of several compounds in all samples. All the essential oils contain alpha-Pinene, d-limonene and eucalyptol as the main constituent. The 1,8-cineole constituent of the oil is ranging from $61.04 \%-73.90 \%$. The highest Cineole $(73.90 \%)$ was obtained for the oldest Eucalyptus globulus tree (100 years old plant) in this work suggesting age difference causing oil content variation. The oils obtained from aged Eucalyptus globulus plant could be used for medicinal purpose but in the case of lowest age needs purification to make its 1,8-cineole content greater than $70 \%$. In general, these findings will help to access the quality of the Eucalyptus oil which is important in the production of high value essential oils.

\section{ACKNOWLEDGMENT}

The authors are very grateful to Debre Berhan University of Ethiopia for providing laboratory facilities and Ministry of Science and Technology of Ethiopia for financial support.

\section{CONFLICTS OF INTEREST}

The author declares that no conflicts of interest.

\section{REFERENCES}

1. Bignell CM, Dunlop PJ, Brophy JJ, Jackson, JF. Volatile leaf oils of some Southwestern and Southern Australian species of the genus Eucalyptus part VI-subgenus symphyomyrtus, section adnataria. Flav Fragr J. 1995;10:359-641.

2. Brooker MIH, Kleinig DA. Field Guide to Eucalypts, 2nd edn., Bloomings Books: Melbourne, Australia. 2004;3:24.

3. Gilles M, Zhao J, An M, Agboola S. Chemical composition and antimicrobial properties of essential oils of three Australian Eucalyptus species. Food Chem. 2010;119:731-737.

4. Edris E. Pharmaceutical and therapeutic potentials of essential oils and their individual volatile constituents: A review. Phytotherapy Res. 2007;21:308-323.

5. Bakkali F, Averbeck S, Idaomar M. Biological effects of essential oils-A Review. Food and Chem Toxicol. 2008;46:446-475.

6. Jae-Seoun Hur JS, Ahn SY, Koh YJ, Lee C. Antimicrobial properties of cold-tolerant Eucalyptus species against phytopathogenic fungi and food-borne bacterial pathogens. Plant Pathol J. 2000;16:286-289.

7. Tsiri D, Kretsi O, Chinou IB, Spyropoulos CG. Composition of fruit volatiles and annual changes in the volatiles of leaves Eucalyptus camaldulensis dehn. growing in Greece. Flavour Fragr J. 2003;18:244-247.

8. Sefidkon F, Assareh MH, Abravesh Z, Barazandeh MM. Chemical composition of the essential oils of four cultivated Eucalyptus species in Iran as medicinal plants (E. microtheca, E. spathulata, E. largiflorens and E. torquata). Iran J Pharm Res. 2007;6:135-140.

9. Goodger JQD, Woodrow IE. Selection gains for essential oil traits using micropropagation of Eucalyptus polybractea. J Forest Ecol Manag. 2000;255:3652.

10. Iqbal Z, Akhtar M, Qureshi TM, Akhter J, Ahmad R. Variation in composition and yield of foliage oil of Eucalyptus Polybractea. J Chem Soc Pak. 2011;33:183.

11. Barton AFM, Tjandra J, Nicholas PG. Chemical evaluation of volatile oils in Eucalyptus species. J Agr Food Chem. 1989;37:1253-1257.

12. Wilson ND, Watt RA, Moffat AC. A near-infrared method for the assay of cineole in Eucalyptus oil as an alternative to the official BP method. J Pharm Pharmacol. 2001;53:95-102. 
13. Boukhatem MN, Kameli A, Ferhat MA, Saidi F, Mekarnia M. Lemon grass (Cymbopogon citratus) essential oil as a potent antiinflammatory and antifungal drug. Libyan J Med. 2014;8:1-5.

14. Mohammed MH, Ibrahim MA, Elsheikh SE. Accelerating matchmaking of novel dysmorphology syndromes through clinical and genomic characterization of a large cohort. Intern Lett Chem Phy Astron. 2013;9:25-30.

15. Batish DR, Singh HP, Kohli RK, Kaur S. Eucalyptus essential oil as a natural pesticide. Forest Ecol Manag. 2008;256:2166-2174.

16. Takahashi T, Kokubo R, Sakaino M. Antimicrobial activities of Eucalyptus leaf extracts and flavonoids from Eucalyptus maculata. Lett Appl Microbiol. 2004;39:60-64.

17. Amakura Y, Umino Y, Tsuji S, Ito H, Hatano T. Constituents and their antioxidative effects in Eucalyptus leaf extract used as a natural food additive. Food Chem. 2002;77:47-56.

18. Cimanga K, Kambu K, Tona L, Apers S, De Bruyne T. Correlation between chemical composition and antibacterial activity of essential oils of some aromatic medicinal plants growing in the Democratic Republic of Congo. J Ethnopharmacol. 2002;79:213-220.

19. Lee KG, Shibamoto T. Antioxidant activities of volatile components isolated from Eucalyptus species. J Sci Food Agr. 2001;81:1573-1597.

20. Gramann J, Hippeli S, Dornisch K, Beuscher N, Elstner EF. Antioxidant properties of essential oils. Arzneim Forsc Drug Res. 2001;50:1.

21. Juergens UR, Dethlefsen U, Steinkamp G, Gillissen A, Repges R, et al. Anti-inflammatory activity of 1.8-cineol (eucalyptol) in bronchial asthma: A double-blind placebo-controlled trial. Resp Med. 2003;97:250-256.
22. Bakkali F, Averbeck S, Idaomar M. Biological effects of essential oils-A review. Food Chem Toxicol. 2008;46:446-475.

23. Boukhatem MN, Kameli A, Ferhat MA, Saidi F, Tayebi K. The food preservative potential of essential oils: is lemongrass the answer. J Cons Protect Food Safety. 2014;9:13-21.

24. Djaafar Z, Ridha OM. Phytochemical study of selected medicinal plant, solanum Nigrum, the Algerian Desert. Intern Lett Chem, Phy Astron. 2014;1:25-30.

25. Subramanian PA, Gebrekidan A, Nigussie K. Yield, contents and chemical composition variations in the essential oils of different Eucalyptus globulus trees from tigray, northern Ethiopia. J Pharmaceu Biomed Sci. 2012;17:17.

26. Boukhatem MN, Amine FM, Kameli A, Saidi F, Walid K, et al. Quality assessment of the essential oil from Eucalyptus globulus Labill of Blida (Algeria) origin. Intern Lett Chem Phy Astron. 2014;17:303-315.

27. Khan AM, Khatun S, Hossain MK, Rahman ML. Characterization of the Eucalyptus (E. Globulus) leaves oil. J Bangladesh Chem Soc. 2012;25:97-100.

28. Joshi A, Sharma A, Bachheti R, Pandey DP. A comparative study of the chemical composition of the essential oil from Eucalyptus globulus growing in Dehradun (India) and around the world. 2016.

29. Zhang J, An M, Wu H, Stanton R, Lemerle D. Chemistry and bioactivity of Eucalyptus essential oils. Allelopathy J. 2010;25:313-330

30. Song A, Wang Y, Liu Y. Study on the chemical constituents of the essential oil of the leaves of Eucalyptus globulus Labill from China. Asian J Traditional Med. 2009;4:34-140. 